and 29 cannot be accounted for entirely by the smoothing process, but is a real feature of the observed interplanetary and geomagnetic fields. Examination of unsmoothed data has also revealed that terrestrial effects were either delayed or persisted longer than corresponding interplanetary disturbances for some events earlier in the history of the flight, although never with phase differences as large as that seen late in April.

An increasing delay toward the end of the period of acquisition of data might be expected to result from the steadily advancing distance between Earth and probe, on the assumption the satellite was intercepting disturbances of solar origin travelling toward the Earth. However, based on the approximate 1,000 $\mathrm{km}$./sec. average velocity usually inferred for transient solar-terrestrial magnetic effects, the expected delay between Pioneer $V$ and the Earth, even for distances in effect at the end of April, would be less than $3 \cdot 3$ hr., and thus imperceptible in the scale of Fig. 2. Long delays due solely to increase in time of probeEarth passage would require local velocities close to $100 \mathrm{~km}$. $/ \mathrm{sec}$. to account for the observed shifts, therefore ruling out solar effects moving by the payload at ten times this speed.
Suggested interpretations of the time displacements include a low payload-Earth velocity and a terrestrial delay mechanism, and the possibility that excursions observed in the interplanetary region and at the surface of the Earth are related respectively to different phases of the travelling storm phenomenon. Further investigation of the data is now in progress.

Acknowledgment is due to Dr. E. J. Smith and Dr. J. M. Kelso for useful discussions and to M. Saxe for help in preparation of the data used above. P. J. Coleman, jun., was responsible for reduction of the Pioneer $V$ magnetic data.

The programme is sponsored by the United States National Aeronauties and Space Administration.

${ }^{1}$ Coleman, jun., P. J., Sonett, C. P., Judge, D. L., and Smith, E, J., $J$, Geophys. Res., 65, 1856 (1960).

${ }^{2}$ Coleman, jun. P. J., Davis, I., and Sonett, C. P., Phys. Rev. Letters, 5,43
$(1960)$.

${ }^{3}$ Sonett, C. P., Judge, D. L., Kelso, J. M., and Sims, A. R., J. Geophys. Res., 65, 55 (1960).

" Sonett, C. P., Phys. Rev. Letters, 5, 46 (1960).

${ }_{5}^{5}$ Lincoln, J. V., J. Geophys, Res., 65, 2198 (1960)

- Lincoln, J. V., J. Geophys. Res., 65, 2470 (1960).

7 Bull. No 12h. Intern. Assoc. Terres. Mag. Elec. (LATME).

'Bull. No. 12h, Intern. Assoc. Terres. Mag. Elec.

'Lincoln, J. v., J. Geophys. Res., 65, 4195 (1960).

\title{
OBITUARIES
}

\section{Prof. W. T. Astbury, F.R.S.}

WirH the death of Prof. W. T. Astbury on June 4, at the age of sixty-three, the world of crystallography, fibres and molecular biology lost an international figure.

A product of the 'Five Towns', eldest son of a large family, versatility at Longton High School earned a scholarship to Jesus College, Cambridge, where, with a break by service in the Royal Army Medical Corps, he graduated in physics in 1921.

The first phase, 1921-28, of his working life was one of tutelage and growth as assistant to Sir William Bragg, first at University College, London, then, from 1923, at the Davy Faraday Laboratory of the Royal Institution where "in that dawn 'twas bliss to be alive", the happy coterie including Müller, Shearer, Bernal, Yardley, Robertson, Robinson and Cox. There he learnt the lessons of simple and direct experiment, the fine tradition of 'Friday Evening' exposition, the value of collaboration. Notable early work on essential systematics and technique of X-ray crystal analysis were the famous space-group tables with Yardley and the $\alpha$-ray integrating photometer. Bold attempts at key structures like tartaric acid and the acetyl acetones were necessarily sketchy; introduction to his life-work came in preparing fibre X-radiograms for Bragg's lectures "On Common Things".

In 1928, Astbury found a field ready for his talents as lecturer in textile physics, University of Leeds, Bragg sustaining him in early difficulties. Five years solid work produced papers in the Philosophical Transactions of the Royal Society on the structure of hair, wool and related fibres which laid for a generation the foundations of high-polymer structural studies. Briefly, inspired analysis of the vague $X$-ray diffraction pictures of biological fibres under varied conditions of humidity, temperature, tension and chemical treatments, related to optical, mechanical, chemical and technical features, led to a broad scheme of keratin structure: the $\alpha \rightleftharpoons \beta$ polymorphic transition as reversible intra-molecular chain folding, the folds plausibly related to side-chains and $S-S$ links to explain 'set' and supercontraction. This brought academic and industrial recognition, welcome financial support, and award of the Royal Institution's quaintly worded Actonian Prize.

Extension to muscle and collagen established two broad classes of fibrous protein structure, while similar work on egg albumen and on protein layers emphasized ehain folding as a key to fibrous and globular protein relations. These, with ad hoc studies of dyeing and tanning and his 'missionary' Fundamentals of Fibre Structure, impressed old trades with new knowledge. It was the creative period.

When not abroad, the rest of his life, from 1955 in doubtful health, was spent in Leeds developing such themes, as reader in 1937 (later honorary) and, from 1945, as professor of biomolecular structure. Polypeptides, cellulose, alginates; the vital structures of flagella, nucleic acids, muscle components; excursions on the abnormalities of cancer, influenza, rheumatism or 'pili torti'; new tools; all was his oyster. About 150 publications in some thirty journals indicate his range and energy. His star shone brightly afar, attracting in all benefactions exceeding $£ 100,000$. Rather silent among his peers, he yet gave generous service to governmental and industrial planning committees, to the councils of scientific and professional bodies, to editorial boards, international conferences, industrial consultancy; and to furthering the work of others. Honours coming thick included an honorary D.Sc. Strasbourg, distinguished medals and monetary awards, foreign membership of the National Academies in Sweden and the United States, and (with A. V. Hill) honorary founder-membership of the British Biophysical Society. His quick wit and breezy style made him a 
popular choice for memorial lectures such as the Procter, Mather, and Sylvanus Thompson.

Astbury's importance lies in the questions he asked and when-stimulus rather than detailed answer. He was an individualist, poet, shy and unsure rather than leader, artistic amateur not scientific professional, Elia his fellow, his strength and weakness the courage and zest the egoisms of a boy, and 'ware the colleague who had to "be of no school and have no master". He brought his findings to market in the green ear, but would not clear the weeds nor suffer the system and technique necessary for the harvest. Inevitably the protein-structural breakthrough was lost, and it hurt. Yet at bottom he had the humility of giants, kindly to failure and to youth, and one warmed to the Croonian and Harvey lecturer who obediently yielded the pavement to a youthful fellow-dreamer chugging along his imaginary track. If he relished the quip 'physicists and stampcollectors' his view of biological research was latterly more akin to Hinshelwood's than to Rutherford's.

"I have ventured,

Like little wanton boys that swim on bladders,

This many summers in a sea of glory,

But far beyond my depth."

$\mathrm{He}$ would rest content with the simple tribute 'salute to adventurers'. Married in 1922, he leaves a widow, son and daughter.

I. MAcArthur

WHEN I joined Sir William Bragg's team in the Department of Physics at University College, London, in 1922, W. T. (Bill) Astbury was decidedly the most colourful personality there. $\mathrm{He}$ took me under his wing and helped me in every possible way. I think it was partly his natural kindness and partly the fact that his intense happiness in his recent marriage to a lovely young Irish girl made him feel fatherly towards all young people. He was so full of enthusiasm for his work that none of us could feel it to be drudgery, even though it entailed sitting for hours on end with one eye glued to a microscope taking readings of the movements of a gold leaf. He was so delightfully pleased with his own achievements, not only then but throughout his life, that it was impossible not to rejoice with him; and he did achieve miracles with what would have seemed to most people almost intractable problems. Any discussion in which he took part, whether it was about crystal symmetry or about politics, became at once a matter of the greatest interest; any game that he played (and especially our lunch-hour international table tennis tournaments at the Royal Institution) became the more lively because he took part: the normal game was often too slow for him, and he would initiate some twist (five marks extra for hitting the matchbox off the table) to make it more fun. I count myself fortunate to have been one of his friends and colleagues.

\section{KaTHLEen LONSDALF}

\section{Mr. W. V. Lewis}

William Vadghan Lewis, lecturer in geography at Cambridge and Fellow of Trinity College, was killed in a motor accident at De Witt, Iowa, on June 8. His work gave him a high standing among geographers in Britain and abroad. With his exceptional eloquence and vitality, he was a born teacher. He was a good friend and had an enduring influence on the lives of many people. His early death comes as a great shock.
Vaughan Lewis was born at Pontypridd in 1907, and was educated at Pontypridd County School. He went up to Gonville and Caius in 1926 and so began a life-long connexion with Cambridge. He read Part I of the Mathematical Tripos, then turned to geography, finding his enduring interest in physiography. After completing the Tripos in 1929 he remained, first as a student, and then as a University demonstrator. Ho became a lecturer in 1945 , when 'freezing' of University appointments ended. In 1949 , to his great pleasure, he was elected a Fellow of Trinity College.

Vaughan Lewis's research career began when Prof. (then Mr.) Steers took him to Scolt Head Island. He was intrigued immediately with problems of coastal deposition and morphology, turning his own attention to Dungeness. He was engaged mainly with coastal research, until in 1936 he visited Iceland and became a confirmed glaciologist. While this was the field of his greatest influence, he typically enlarged, rather than ehanged, his interests, later doing much research on Chesil Beach, the results of which remain to be published. $\mathrm{He}$ had also a secondary interest in hydrology.

His glaciological work, carried out mainly in Norway and Switzerland, was concerned particularly with aspects of the structure, flow and erosive influence of cirque and valley glaciers. Apart from his published contributions to glaciology, such as his lively exchanges on the cirque problem with $\mathrm{D}$. W. Johnson, it should be recorded that he was personally responsible for making physicists interested in fieldwork on glaciology. He played a leading part in the affairs of the British Glaciological Society, which has much enhanced latterly the active development of glaciology in Britain and elsewhere. Vaughan Lewis initiated two intensive research projects in Norway. The results of the earlier investigation of cirque glaciers were published in a research memoir of the Royal Geographical Society, of which he was the editor. His personal interests in the Austerdalsbreen Valley glacier project are recorded in a recent joint paper in the Glaciological Journal. These investigations depended on the co-operation of numbers of workers in different fields, and on the active support of generations of Cambridge undergraduates and research students. Vaughan Lewis again and again caught the real interest of undergraduates and, naturally, gathered around him eager groups of volunteers for field-work. The range and vividness of his ideas were such that he had a catalytic effect on the work of others. He was always generous, and would continue to encourage and assist those whom he had inspired to undertake some investigation. He will be sadly missed in many places.

JeAN M. Grove

\section{Mr. Geoffrey Parr}

Writr the death of Geoffrey Parr on May 30 at the comparatively early age of sixty-one, a colourful and popular figure leaves the scientific world. Parr received his formal education as an electrical engineer at the Finsbury Technical College, and, after working for the Admiralty during the latter part of the First World War, became a lecturer and demonstrator at the City and Guilds Technical College. In 1926 he joined the Research Department of the Edison Swan Electric Co., Ltd., where the cathode-ray tube was undergoing some of its early developments. Then in 1932 he took charge of the same Company's Technical Service Department. 